\title{
Otherness in Autism: From the Fellow Human-Being to the Other Synthesis
}

\author{
Andréa Di Pietro* (1) \& Angélica Bastos (D) \\ Universidade Federal do Rio de Janeiro, Rio de Janeiro, RJ, Brazil
}

\begin{abstract}
The present article investigates an essential question raised by the experience of the psychoanalytic clinic of autism: otherness. The goal of this research is to establish the specificity and the variety of forms of otherness in autism. From the Freudian premise of the complex of the 'fellow human being' (Nebenmensch) to the distinction between this and the Other as a place of language, this research examines the forms of otherness that can arise in autism, such as identified by J.-C. Maleval. They are as follow: the autistic object, the double, and the synthetic Other. For this purpose, this paper finds support on life events narrated by autistics as well as clinical fragments from the specialized literature.
\end{abstract}

KEYWORDS: psychoanalysis, autism, otherness, synthetic Other

\section{A Alteridade no Autismo: do Próximo ao Outro de Síntese}

\begin{abstract}
RESUMO - O presente artigo investiga uma problemática suscitada pela experiência clínica e essencial à psicanálise com autistas: a alteridade. O objetivo da pesquisa consistiu em estabelecer a especificidade e a variedade das formas de alteridade nesses casos. Partindo da premissa freudiana do complexo do próximo (Nebenmensch) e passando pela distinção entre o próximo e o Outro enquanto lugar da linguagem, a pesquisa percorre as formas de alteridade suscetíveis de se delinearem no autismo, tais como identificadas por J.-C. Maleval: o objeto autístico, o duplo e o Outro de síntese. Para tal, recorre a relatos de vida narrados pelos autistas e a fragmentos clínicos da literatura especializada.
\end{abstract}

PALAVRAS-CHAVE: psicanálise, autismo, alteridade, Outro de síntese

Early on, psychoanalysts who work with children had to respond to the status of the subject with whom they operated: would there be in this clinic, a subject in the strictest sense, as the experience of the unconscious implies? The psychoanalysts answered affirmatively, claiming that the subject of the unconscious is not an infantile subject since the infantile, whether of sexuality or neurosis, involves a structure. That is, there is no pre-subject nor progressive gradations in its manifestations.

The increasingly precocious moment in which children were accepted into psychoanalytic treatment highlighted the dimension of betting on the subject, of anticipation, so, as it is in any analysis, the subject can arise. Parents' participation in the treatment was constantly questioned: how and why including them in the analysis if the Other of the subject depends on the writing of the unconscious, that is, since Freud, the psychic reality par excellence? Despite the distinct approaches that the issue received, depending on the psychoanalyst's orientation, the complex matter that we call otherness was highlighted.

The clinic with the so-called autistics, the reading of their testimonies, and the empirical literature on these subjects, bring us the question about the status of otherness in these cases. The refusal or the indifference towards people, the non-distinction between the subject and the other (frequently illustrated in the scene where they take someone else's hands to perform some activity) as well as mutism and echolalic speech, all attest to a particular position in relation to people and language. Such a position led many psychoanalysts to formulate that, for autistics, the Other is not constituted and does not exist. However, if we do not believe in the construction of otherness in autism, how can we sustain

*E-mail: andreadipietro2@gmail.com

- Submetido: 03/07/2018; Revisado: 13/09/2019; Aceito: 02/11/2019. 
betting on the subject, which is essential to the clinical work? Psychoanalytic treatment develops itself under transference; that is why it is necessary to conceive the latter, although the current concepts of otherness in the clinical cases do not automatically apply to autism. Based on the observation that the psychoanalyst's presence counts for the autistic, who responds to it and works with him, we will concentrate this work on the question about otherness, in order to collect elements for its treatment.

When writing books or giving lectures, the so-called high-functioning autistics demonstrate that they have found a way to deal with the otherness. In these cases, they have friends, some get married, their speech is clear and elaborated, and they seem to have assumed a body image. These accounts allow us to observe specific ways in which they could deal with others, make use of language, and talk about themselves. For instance, they often resort to a double, such as Donna Williams, a high-functioning autistic who became known from the accounts she produced about her experience. In one of her books, Donna Williams (1992/1999) explains the use she made of two characters, Willie and Carol, who served as protection - when she embodied them in specific situations - and allowed her to open herself up to the world. In her book, she explains: "This was to signify that they were not communicating with Donna, only with the characters which I felt they were worthy of" (Williams, 1992/1999, p.55). The use that so-called autistics make of language also has its specificities. We observe a refusal to occupy a position of enunciation, either by mutism or by verbiage. In addition, they declare a preference for words that have a concrete reference, that is, that may have their meaning attached to an image or a thing.

Based on the clinic and on the reading of these testimonies, we noticed that autistics protect themselves from an unbearable presence, which led us to formulate the hypothesis that the otherness concerning them would be that of the "fellow human-being" - the Nebenmensch, in German. The one who carries out the extraneous help, according to Freud (1895/2006), but who is also a hostile object. Lacan will resume and differentiate this figure from the Other as symbolic otherness: the Nebenmensch is an intolerable imminence of jouissance, while the Other is the result of a sweep of jouissance operated by the incidence of the signifier, which may not occur. We will follow the hypothesis of Jean-Claude Maleval, a psychoanalyst who proposes the synthetic Other for autistics, constituted not by signifiers, but by signs; as a way of expanding existing constructions that were so far problematic in the theories on autism.

In order to develop a reading that does not consider autism a deficit, a failure in relation to the structuring of neurosis or even psychosis, but rather an original and radically singular way of being in the world, this article aims to overcome the statement that the Other was not constituted for these subjects. For that, it explores original ways in which autistic subjects seem to be able to limit jouissance and construct otherness, tracing a path that goes from the fellow human-being to the synthetic Other, passing through the autistic object and the double. Even though the functions become more complex as we follow this path, it is essential not to take them as developmental stages to be overcome.

\section{NEBENMENSCH,THE FELLOW HUMAN-BEING}

In the text Project for a scientific psychology (1895/2006), Freud approaches the initial helpless state in which human beings are found when they are born. He proposes that, when affected by an excess of excitation, the psychic apparatus suffers an urgent need for discharge by the motor end and, thus, there are two possible routes. The first one, of internal change, corresponds to the expression of emotions, which is unable to stop receiving endogenous stimuli and produce relief. The second path entails a specific action, which corresponds to an alteration in the external world, producing as a consequence the temporary suspension of excitations in the psychic apparatus. For instance, in the case of hunger, the specific action would correspond to seeking food in the environment.

However, the human baby is incapable of bringing out the specific action autonomously. It is facilitated by extraneous help, that is, by an experienced person who will respond to the manifestations caused by the internal change. The figure of the Nebenmensch, the fellow human-being, appears as the first object of satisfaction, at once the first hostile object and also the subject's only auxiliary force. The crying and the screaming are incapable to end the state of urgency and, when they come from someone else, they evoke in the subject their own experiences of pain and displeasure (Freud, 1895/2006).

By considering the crying as an appeal and by giving it a meaning, interpreting as hunger, sleep, or whatever, the one who occupies herself with the child offers her signifiers, summoning the child to the symbolic world. The experience of the satisfaction of the drive, "entirely suspended to the other" (Lacan, 1959-60/2008, p.53, our translation), becomes, then, associated with the incidence of the signifier.

Nonetheless, it is not enough to have a fellow human being who talks to the child so the latter can enter into the symbolic world, conceiving the place of the Other. The Nebenmensch is the precursor of the Other, but they do not coincide. It is from the fellow human being, and because he is a speaking being, that the Other will be constituted as a place of the signifier. However, from the Nebenmensh to the Other there is a step to be taken. 
Lacan (1968-69/2008) questions whether the Nebenmensh, the fellow who grants the extraneous help, would be the Other, the one who serves to make the signifier articulation in the unconscious work. His answer is negative:

This fellow creature, this neighbor, is it what I have called the Other, what I make use of to make function the presence of signifying articulation in the unconscious? Certainly not. This fellow creature is the intolerable imminence of jouissance. The Other is only its cleared out terreplein. (...) The Other is precisely that, a terrain cleared out of jouissance. It is there, in the Other, that there is the unconscious structured like a language. (Lacan, 1968-69/2008, p.219, our translation).

In this way, we are sent to a logical time that precedes the constitution of the Other and the unconscious structured according to the laws of language, indicating that the Other has not been there since the beginning. It is necessary to clear out the field of jouissance, by the signifier, in order for the Other to be established. However, autistics present distinct inventions through which they come to organize the reality, locating and limiting jouissance which, in turn, was not mortified by the signifier and hence invades them.

\section{THE AUTISTIC OBJECTS}

Temple Grandin (Grandin; Scariano,1986/2014), one of the most well-known high-functioning autistics in the world, reports that, since second grade, she thought of a machine that could put pressure on her body in an intense and pleasurable way. The most interesting thing for Grandin was the possibility of having this machine always at her disposal, as well as its intensity and pressure control. The machine was gradually built and perfected in her mind. On a visit to an amusement park, she discovered and experienced an attraction called the rotor, an immense cylinder that spun at high speed and, by its centrifugal force, kept people back attached to the wall to, then, retract the floor. Grandin tells that she felt comfortable and relaxed, becoming fascinated by the rotor and willing to have one at school which, logically, was not possible. Years later, inspired by her aunt's farm cattle chutes, Grandin built her own pressure machine.

In the clinic with the autistics, it is very common to observe the association with objects that range from a piece of wire, a car wheel or a fork, to the construction of complex machines, such as that of Temple Grandin.

Frances Tustin was the first to conceptualize autistic objects, but even recognizing their protective function, she attributed a pathological character to them. The psychoanalyst considered these objects as precursors of Winnicott's transitional objects with the differences that autistic objects have no substitutes, function as a protection against loss, and are able to merge with the child's body. Tustin (1992) refers to the use that so-called normal children make of substitutes for the mother who breastfeeds (such as the pacifier or the child's finger) when they miss her. They are temporary substitutes that allow the baby to wait until the mother returns to feed them. In contrast, the autistic objects would function as glued to the body, occupying the place of the maternal breast and blocking the ability to discern the maternal care (Tustin, 1992). Although she differentiated these objects, Tustin (1992) admitted that, in some cases, a transitional object and an autistic object could merge.

Temple Grandin (Grandin; Scariano,1986/2014) comments that she was afraid that the cattle chute would take her and prevent her from living without it. However, she eventually took it as "just an immobilization device made of plywood remains" (p.97, our translation) and, for that reason, she could have access to the thoughts and feelings she had on the chute also outside of it. She denies the hypothesis on her machine serving as a substitute for her mother's hugs. On the contrary, Grandin affirms that the chute allowed her to get closer to her mom as well as to other people.

When I entered into the chute, I felt closer to people like my mother, Mr. Peters, Mr. Brooks, Mr. Carlock, and aunt Ann. Although it has been just a mechanical device, the chute broke down my tactile defensive barrier, and I could feel the affection and concern of these people, managing to express my feelings for myself and for others. (Grandin; Scariano, 1986/2014, p.97, our translation)

Contrary to the position of Frances Tustin, as well as to that of educators and most of psychologists who are anchored in a normative approach to development, the psychoanalyst Jean-Claude Maleval (2009) does not take these objects as pathological or harmful. He considers what autistics say about the objects: Birger Sellin says he finds security in them; Temple Grandin says she is more interested in the objects than in people; Donna Williams explains she took the people she loved as objects that protected her from those she did not like. "For me, the people I liked were their things, and those things (or things like them) were my protection from the things I didn't like - other people" (Williams, 1992/1999, p.13).

Maleval (2009) also highlights Grandin's suggestion for educators: instead of trying to eliminate the objects and stereotypes, they should seek to transform them into a source of motivation towards new learning since, alike her own experience, these fixations can turn into a professional career. In many cases, autistic objects participate in the so-called "islet of competence" (Maleval, 2017, p.377, our translation) and offer autistic subjects the possibility to develop careers and achieve financial independence. 
Maleval (2009) is also opposed to the idea that autistic and transitional objects can merge as he considers them to be radically different. The main discrepancy between the two types of objects refers to the satisfaction regime. This can be understood by comparing the Fort-Da and the on-off conducts.

In the children's play described by Freud in his text Beyond the pleasure principle (1920/2006), the one-and-ahalf-year-old boy held his bobbin by the string, threw it until the object disappeared while he said "o-o-ó", corresponding to "fort" - a German word for "go away". Then, he pulled the bobbin back and greeted his reappearance by saying "da" ("there"). The first scene, the most unpleasant, was the one that was repeated most. Freud interprets this play as a great cultural achievement, a renunciation of the drive just like the one that the child made when he let his mother go away and be absent, without protests.

In the example of the on-off conduct used by Maleval (2009), an autistic boy, for whom all objects seem edible, tries to treat the excess of his oral jouissance by resorting to a book. He selects the images in the book that relate to food, names, and subjects each one of them to two times, those of presence and absence: "strawberries/no more strawberries; potatoes/no more potatoes". At a later time, he starts mobilizing the opposition in relation to other objects (a snowman, a boy, etc.), always alternating between "there is/there is no more".

On one hand, the bobbin is a transitional object since it presents itself as a treatment for a loss, for an already established lack, and it articulates two signifiers in the middle of which there is a staging of a loss. Differently, on the on-off behaviors, the first expression does not name an absence, but rather a presence, and the second one does not greet a reappearance, but the placement at a distance. Although the activity of autistic children in relation to the on-off behaviors reveals an attempt to bring about a controlled loss of an excessively present object and to inscribe the discontinuity principle of human language, there is no second signifier for which the missing thing designated by the first (signifier) is represented. There is no satisfaction in making it reappear, at the same time it kills it. There is a sign of presence and a sign of taking distance that still carries the designated thing instead of renouncing to it, of assuming its loss. According to Maleval (2009), "the on-off and the Fort-Da behaviors seem like two ways of treating the negativity of language and the pain of losing an object; however, one works with the sign while the other with the signifier" (p.233, our translation).

Maleval (2009) divides autistic objects into two categories: simple objects and complex objects. The majority of simple objects are rough and dynamic, aiming to treat the body image and the libidinal animation. In the experience with the rotor, for instance, Temple Grandin describes that her senses were so overloaded with stimuli that she no longer reacted with anxiety or fear, but on the contrary, with comfort and relaxation. Nonetheless, as soon as autistics disconnect themselves from it, they lose the vitality the object gives them. Simple objects function as a protective rim which often works as a barrier to the social field. Complex objects, on the other hand, have the main functions of framing jouissance in a rim outside the body and allowing the autistic to connect himself to the social field (Maleval, 2009).

The idea of a rim is initially paradoxical when we refer to autistics, once they present a great difficulty in constructing a body image with boundaries and holes. However, Laurent (2014) explains that it is precisely due to the absence of a construction of a body that the concept of the rim could be invented, stemming from the idea of a carapace that closes, isolating the autistic from the Other. It is a forged rim that Laurent (2014) will call a neo-rim: "[a] place where the subject is situated, place of massive defense, a place of pure presence" (Laurent, 2014, p.79, our translation). The psychoanalyst bets on the displacement and relaxation of this neo-rim, so that a space that is neither of the subject nor of the Other, can be created. The use of objects is essential for something to be extracted and for the neo-rim to be displaced (Laurent, 2014).

Laurent (2014) divides the objects without form and the in-form of object a. Regarding Temple Grandin's hug machine, he affirms that it gives a form to the "panicstricken" object gaze - highlighted by Grandin in herself and in the cattle that she observes - and articulates it to the body. There is a capture of object $a$ by the shape of the object and then by the body. To compare this case of in-form of object $a$ with that of an object without form, Laurent (2014) resorts to the practice, already observed in some autistics, of extracting their own feces by introducing the hand into the anus. In this second case, it is an object of jouissance without form, different from the object that makes suppléance to the absence of boundaries in the body, and that protects it from the anxiety of an intrusion, as in the case of Grandin's machine. In this second case, it is the object, as a trace of the living, that needs to be extracted, "radical otherness that needs to be abolished" (Laurent, 2014, p.88, our translation). Instead of functioning as an anal object given up in the circuit of the demand, the brutal extraction of feces does not get separated from the body, maintaining it articulated to the latter; they are extracted as a repetition of an object without form, radically rejected (Laurent, 2014).

We have seen that even simple objects present the functions of locating jouissance and assisting in the construction of a body image. Yet, the processes of treating jouissance through the object and through language can be united in a more intimate and complex way, when they are articulated to the double. 


\section{THE AUTISTIC DOUBLE}

Tustin had already announced that the objects served as a double to the subjects (Maleval, 2009). However, there are multiple clinical forms of the autistic double: it can be an object, an animal, another person, or one's own image in the mirror. According to the testimonies of so-called highfunctioning autistics, there is also the invention of characters that have the function of the double, as were Willie and Carol for Donna Williams, or Alfred Costello and Bischan for Temple Grandin. As noted by Maleval (2003), "nothing is more characteristic of the autistic than his capacity to connect himself to a double in order to open himself up to the world" (Maleval, 2003, p.204, our translation). The use of a double can offer protection against the imminence of jouissance of the other and allow these subjects to acquire knowledge without having to enter into the dialectic of exchange, so anguishing for inciting the dimension of the lack (Maleval, 2003).

In her struggle to have a toy like the rotor at school, Temple Grandin uses a character created by her during her childhood, Alfred Costello, "the shadow". When writing on behalf of the character, Grandin was able to elaborate several letters in which she requested the installation of the toy, claiming that only through this way his representative, Temple Grandin, could save the school and its students from a threat of disappearance. Through this character, she protected herself from the position of enunciation, so deadly to autistics, at the same time she made her claim. According to Maleval (2017), it is a way to speak while being absent, a way to express oneself "by proxy" (p.133, our translation), which protects the subject from the Other's desire. Nonetheless, the double is not capable of knotting language and jouissance so that the subject doesn't have the perception of being connected to his feelings; there is a psychic mutilation that makes the double unintegrated with the subject (Maleval, 2017).

Rosine Lefort and Robert Lefort (1980/1990) report two cases treated at the Parent de Rosan Institute: Nadia and Marie-Françoise. The comparison between both cases - the first, a neurosis; the second, an autistic girl - had the effect of an important contribution about the difference between the mirror stage in the structuring of neurosis and the construction of the double in autism. Observing the first encounters with both patients, especially in what concerns the analyst's body, Lefort and Lefort (1980/1990) raise the hypothesis that marked their approach on autism - the inexistence of the Other as well as the small other:

If we refer to Nadia, as I said, I have to be amazed by MarieFrançoise's violence in her body contact with me. In fact, for Marie-Françoise, it is not the exploration of the hole in my mouth - of my pierced body - that is at stake, as much as she

1 "Rien n'est plus caractéristique de l'autiste que sa capacité à se brancher sur un double pour s'ouvrir au monde." is not interpellated by the presence of a small other, as Nadia was. What characterizes Marie-Françoise's object relation is that the Other does not exist - much less the small other-, and that for her, I am an object among others. This does not mean that I am not, in a certain way, privileged. (Lefort \& Lefort, 1980/1990, p.194, our translation)

While for Nadia the image in the mirror is the presentification of, at the same time, the Other (Autre) and the other (autre), "A $+\mathrm{a}$ ", the same is solemnly ignored by Marie-Françoise, who is far from any possible identification. Instead of images, the others are real objects for her, among which Rosine Lefort places herself as a privileged object. Marie-Françoise can only find the double in the mirror, which is also all, without loss, as well as without unity, just like her (Lefort \& Lefort, 1980/1990).

In Rosine Lefort and Robert Lefort's detailed description of Marie-Françoise's treatment, we follow the girl's use of her double, a sailor doll, a real object that protects her from the dimension of loss. After taking off the analyst's glasses, hitting them and abandoning them, she takes the sailor doll and sticks it in her eyes:

(...) it is as if she realized, for a brief moment, that she made me lose something by my glasses, a loss that is also valid for her and that she would hold me responsible for, at the same time she would radically refuse it, covering it with the sailor over her eye. (Lefort \& Lefort, 1980/1990, p.245, our translation)

In another scene, Marie-Françoise squeezes the doll, no longer against her eyes, but her diaper, and positions it in a way that is also close to her mouth, so she can obturate two holes. The real double presented by the Lefort couple in the case of the sailor doll has essentially the function of filling holes.

With Laurent (2014), we can consider these holes in the body of autistic subjects as holes without a rim, as a void that appears like an abyss in the accounts of some autistics. The double would function as a rim for a body without one. According to the psychoanalyst, the absence of a rim of the hole is "the unfolding of the inexistence of the body itself, because a body can only exist if an object can be separated from it" (Laurent, 2014, p.100, our translation).

Rosine and Robert Lefort (2003) resume the case of Marie-Françoise and add several observations on the double, considering it an "essential and structural component of autism" (p.27, our translation). When questioning the constitution of an image of oneself in the mirror in cases of autism, they conclude that the flat mirror, that of the place of the Other, does not come between $i(a)$ e $i^{\prime}(a)$, real and imaginary, but rather between two $i(a)$, two real images. The division of the autistic subject takes place in the real of the double (Lefort \& Lefort, 2003). What autistics find in each small other is, for them, a real double. 
(...) neither specular relation nor division of the subject, but a double that the autistic finds in every other, his fellow, whose most acute danger is the imminence of his jouissance and the need to kill in him the part that language has not eliminated, so that the relation with the Other, as a terrain cleared out of jouissance, can be founded. (Lefort \& Lefort, 2003, p.182, our translation)

It is important to point out the difference between the double in psychosis and the double in autism: while the first maintains with the double a relation of rivalry, aggressiveness, and persecution, autistics serve themselves with the double, which has the functions of protection and support to connect to the world (Maleval, 2012b):

(...) the psychotic's double is lived as an autonomous and malicious object, upon which the subject's will is unable to exercise itself, except in order to destroy it. This is not the case for the autistic's double, which is reassuring when it can be brought under control, or when it is admitted among familiar objects." (Maleval, 2012b, p.43)

Donna Williams teaches us a lot about the figure of the double in autism. In her first testimony, Nobody, Nowhere, she narrates the appearance of two characters that accompanied her for many years: Willie and Carol (Williams 1992/1999). For Maleval (2003), it was through them that Donna was able to locate the scopic jouissance, build a body image, and still, these characters were carriers of a knowledge "already there" since they had a close relation with the maternal ideals. Williams introduces them:

"My anger, embodied in Willy, and my ability to perform and communicate embodied in the emotionless and empty shell I secretly called Carol. Others were not even worthy of my explanation which I kept secret from everyone for twenty-three years." (Williams, 1992/2012, p.55)

The figures of the double presented in Donna Williams's testimony were described as "friends who did not belong to this physical world, whom I had welcomed into mine" (p.16). Willie appears before Donna turns 2 and, at first, as a pair of green eyes hidden under her bed. It did not bring her tranquility, but it protected her body from intruders. Donna started sleeping under her bed as a way of becoming Willie and, in her words: "By this time I was three years old. Willie became the self I directed at the outside world" (Williams, 1992/1999, p.17).
It was Willie's incarnation, despite all his hostility, that allowed Donna to open herself up to the outside world. Aggressive like her mother, the character's name derived from her family's name. Thus, Donna's mother saw her as a defective incarnation of her older sister, the first daughter among nine children, who received all the privileges that the siblings did not receive (Williams, 1992/1999).

Carol comes later, from an encounter with a girl whose happiness and liveliness enchanted Donna. She wondered about the reality of this encounter and the existence of Carol, but affirmed that it was this strange person who changed her life: "She became the 'girl in the mirror'. Later I became Carol" (Williams, 1992/1999, p.23). While Willie had green eyes that shone in the darkness and caused fear, "hateful glaring eyes" (p. 17), Carol had the sparkle in her eyes that Donna didn't: "Carol looked just like me, but the look in her eyes betrayed her identity (Williams, 1992/1999, p.24). The location of the gaze object in the figures of Willie and Carol gives us a clear example of the double's function in the treatment of jouissance.

Williams (1992/1999) also gives us examples of the irreducibility of the autistic double to the specular pair, a hypothesis developed by the Lefort couple. After abandoning Willie and Carol, Donna Williams's double got attached to her image in the mirror: she greeted herself and enjoyed spending time in front of the mirror in her own company.

According to Maleval (2003), the double has a protective function and it also contributes to the structuring of a body image. However, its main characteristics are the capacity to frame jouissance, which allows for libidinal animation, and its ability to articulate itself to the synthetic Other. Still, on Donna Williams's figures of double, she affirms:

"Hiding behind the characters of Carol and Willie, I could say what I thought, but the problem was that I could not say what I felt. One solution was to become cold and clinical about topics I might feel something about. Everyone does this to an extent, in order to cover up what they feel, but I had actually to convince myself about things; it made me a shell of a person." (Williams, 1992/1999, p.52)

In the case of Donna Williams, besides locating the scopic jouissance, Willie and Carol articulated themselves to the synthetic Other, allowing Donna to make a singular use of language.

\section{THE SYNTHETIC OTHER}

Lastly, we have what it seems to be the most elaborated autistic defense: the construction of what Maleval first called the Other of suppléance (2003) and, later, the synthetic Other (2017). With the support found in the double, which is capable of treating the libidinal animation, autistics can engage themselves in the treatment of the chaotic external world through the construction of the synthetic Other (Maleval, 2017). It is an Other constituted not by signifiers, 
but by signs. As we saw in the comparison between the Fort-Da play and the on-off conducts, signs are elements that do not accomplish the death of the thing, that is, there is a rigid connection between the word and its referent. This characteristic of being parasitized by the referent, added to the inability to function as receptacles of jouissance, are the two main differences of signs when compared to signifiers (Maleval, 2003).

We know that, among the different signs, autistic children particularly appreciate the icons, that is, signs at least partially justified that schematically represent the entity, the person, the event or the designated attribute (for instance, the $\mathrm{S}$ of traffic signs that designate zigzags, the floor plan of a house, the images of men and women at bathroom entrances, etc.). They appreciate them because the icon constitutes the most appropriate sign for their attempt to encode the world; it immediately reveals the rigid connection between the sign and the referent image. (Maleval, 2003, p.23, our translation)

Although the verbal bath affects the autistic's body, the conversion of the real into signifiers - which in themselves mean nothing - does not occur and the negativity of language affects autistic subjects in a very specific way. From this point, Maleval (2012a) introduces several and complex ways in which autistics deal with language. They are original forms ranging from mutism to the domain of language, including verbiage. What is constant in all these manifestations is the drive functioning and, mainly, the non-cession of the object's voice.

The first exits from mutism are usually through verbose language, starting from sentences, words, or songs that quite often are echolalic. The meaning of what they say is often opaque to other people, however, experience proves they should not be taken frivolously, since there was a choice of the subject in saying those words and not others, in addition to the fact that they are repeated when certain situations are reproduced. Maleval (2012a) mentions as an example the account of the father of an autistic girl who had the habit of singing Alouette while someone combed her hair after showering. Years later, they found that Alouette was equivalent to all wet. It was an utterance separated from the Other of the signifier, a solitary jouissance of the sonorous, although it was applied to a specific situation to which it was related.

According to Maleval (2007), verbiage is a work that aims to separate oneself from the voice that causes horror to autistics. Donna Williams comments that faced with the impossibility of manifesting her feelings, she resorted to verbiage:

"Deep down, Donna never learned to communicate. Anything that I felt in the present still had either to be denied or expressed in a form of conversation others called waffling, chattering, babbling, or 'wonking'." (Williams, 1992/1999, p.52).
If on one hand, these subjects scream and vocalize strange sounds or murmurs that are completely disconnected from meaning, on the other hand, they are capable of isolating speech of musicality and intonation, then producing a speech that is often robotic and linear, which characterizes the functional language. Verbiage and functional speech can be present in the same subject, yet they do not come together. When they do come together and the autistic subject produces an enunciative speech, as in the case of spontaneous sentences, that speech irrupts as a very distressing experience lived with horror, leading the subject to close himself up in an even more profound silence (Maleval, 2012a).

The curious phenomena of spontaneous sentences tell us a lot about the retention of the object's voice as an autistic defense since it is the only manifestation in which this object ceases through the engagement of the voice in speech. They are holophrases, most often of an imperative character that emerge in situations of extreme anxiety and are experienced as automutilation, as noted by Laurent (2014): "The subject utters them as if he were losing a piece of himself, his feces, a jet of saliva, a scream, blood. They are utterances from the body, pieces of jouissance, a kind of automutilation." (Laurent, 2014, p.106, our translation). Maleval (2012a) mentions the example of Birger Sellin, whose first speech was addressed to his father - "give me my ball back" followed by his return to mutism.

Since autistics are reluctant to take a position of enunciation and, on the other hand, suffer from the difficulties imposed by a solitary speech (as it is the verbiage language), some subjects use the functional language in an effort to communicate without mobilizing the vocal jouissance. Maleval (2012a) describes such speech as an accumulation of facts with the characteristic of being an informative code without expression of affects and an enunciative voice. This way of using language is situated in the dimension of speech, not of saying, which goes beyond what is said.

The functional language depends on the construction of the synthetic Other, constituted by signs and not by signifiers. The disconnection between language and emotional life, attested by autistics, shows us that, unlike signifiers, signs do not function as representatives of representation. It is only with the condition of keeping their object aspect, disconnected from the voice and the drive, that signs from the synthetic Other can be mobilized to express the subject's feelings (Maleval, 2003).

These subjects are submitted to the primacy of the sign and have the construction of a code in which each word has a single, fixed meaning as an ideal. Higashida (2014) states that letters, symbols, and signals are his best allies because they never change. "They are always the same, fixed in my memory. (...) I am not alone when I'm with the letters" (p.89, our translation). An example of the rigidity of the sign is given by Temple Grandin (2010), who states that for her a man on a horseback is something completely 
different from a man on foot. Yet, Donna Williams explains she had difficulties with rules that required generalizations:

My behavior puzzled them; but theirs puzzled me, too. It was not so much that I had no regard for their rules as that I couldn't keep up with the many rules for each specific situation. I could put things into categories, but this type of generalizing was very hard to grasp. (Williams, 1992/1999, p.66)

Temple Grandin explained her functioning stating that she thinks in images, comparing herself to the search engine of Google Images. For instance, to the order "think of a church tower", she does not respond by thinking of a general idea of a church tower, but rather by rapidly visualizing a series of church towers she has already seen in her life (Grandin, 2010). For this reason, she states that it is easier for her to memorize nouns than verbs. Even more difficult, she says, is to memorize concepts without being able to take notes - that is, to produce an image of them. In order to memorize abstract notions, she resorts to a technique, which consists of associating the notions with concrete referents: "When I think of abstract concepts like human relationships, I use visual similes - for example, relationships between people are like a sliding glass door that needs to be opened as not to break" (Grandin; Scariano, 1986/2014, p.133, our translation). Temple Grandin's thinking of images works because the image is the most finished form of the iconic sign, which best represents the thing (Maleval, 2003).

The status of signs allows us to understand why Josef Schovanec (2016) states, for example, that it is a great horror for autistics that several people may have the same name. In the ideal autistic code, words have concrete references, in other words, their meaning can be linked to an image or a thing. In this code, each word would have a single meaning attached to it, which would dispense the need for interpretation (Maleval, 2012b). Autistics are disappointed when faced with the fact that language is a system in which the meaning of a word can only be given in function of others (Maleval, 2012b). Insofar as the signifier is separated from representation, it does not represent anything in itself; its equivocity disorientates, deceives, which implies that a subject, when mobilizing signifiers, makes himself represented.

The signs of the synthetic Other can be alphabetic, imaginaries, sonorous. Maleval (2017) differentiates two modalities of the synthetic Other. The first is the closed synthetic Other, which allows the subject to orient himself in a limited world of routines and without surprises. Its rigid and limited functioning is well evident in the so-called savant autistics (Maleval, 2017). They show themselves in search of totalizing knowledge of a restricted domain with immutable rules, and, in this way, they develop an "islet of competence" (Maleval, 2017). Daniel Tammet, for example, became well-known for spending more than five hours reciting the $P i$ 's digits, reaching a total of 22,514 digits. The British Stephen Wiltshire, after seeing a cityscape, is able to memorize and draw with impressive precision all its architecture, faithfully reproducing the windows and doors of each building.

Beyond the closed synthetic Other, there is the second modality designated by Maleval (2017) as open synthetic Other. It refers to the cases in which autistics manage to mobilize the signs in order to develop a dynamic knowledge and, hence, adapt themselves to new situations. While the closed synthetic Other is able to order a solitary and circumscribed world, the open synthetic Other allows the subject to demonstrate some openness to the social bond, which is the case of the so-called high-functioning autistic (Maleval, 2017).

\section{FINAL CONSIDERATIONS}

According to Maleval (2003), when a synthetic Other is built, the presence of the double becomes less pregnant and the use of simple and complex autistic objects is less necessary. Nonetheless, it is important to emphasize that the objects, the double, and the synthetic Other are not developmental stages that can be overcome. The interdependence that exists among them prevents us from clearly separating them: the object functions as a double, it associates itself with an islet of competence, and the synthetic Other is born of a late echolalia from the words of the double (Maleval, 2017).

Laurent (2014) mentions the case of a child treated at Antenne 110, a Belgian institution for autistic and psychotic children and adolescents. From an object elected by the child - a stick - the clinicians sought to complexify her use of it and, in the encounter of the object with the bell of a neighboring church, new slidings were possible. The child showed a fascination with the bass sound of the bell, then she sought to know what time it rang, and finally, she became interested in the needles of the clock. From there, the interest in numbers followed and this child could get involved in the arithmetic classes at school. Here is an example of how a subject can build his synthetic Other based on a singular interest in an object.

By way of conclusion, it is worth saying that otherness is not reduced to the Other as the place of signifiers, and it is up to the psychoanalyst who works with the so-called autistics to accompany them in their manufacture of the objects, the double, and the synthetic Other, whenever this is possible. The othernesses of the self-image - and, hence, that of the fellow human being -, of the real double and the Other of signs, have the given treatment of jouissance, always heterogeneous and demanding of localization, as a condition. 


\section{REFERENCES}

Freud, S. (2006) Projeto para uma psicologia científica. In: S. Freud Edição Standard Brasileira das Obras Psicológicas Completas de Sigmund Freud. (vol. 1, J. L. Meurer, Trans., pp.335-454). Imago. (Original work published 1895)

Freud, S. (2006) Além do princípio de prazer. In: In: S. Freud Edição Standard Brasileira das Obras Psicológicas Completas de Sigmund Freud. (vol. 18, E. A. M. Souza, trad., pp.12-75). Imago. (Original work published 1920)

Grandin, T. \& Scariano, M.M. (2014) Uma menina estranha: Autobiografia de uma autista. ( ${ }^{\mathrm{a}} \mathrm{ed}$.S. Flaksman, trad.) Editora Schwarcz. (Original work published 1986)

Grandin, T. (2010) Temple Grandin: The world needs all kinds of mind. TED Talks. Disponível em: $<$ https://www.ted.com/ talks/temple_grandin_the_world_needs_all_kinds_of minds\#t-170286 > Acesso em: 06 dez 2016.

Higashida, N. O que me faz pular. (R. Durst, Trans.) Intrínseca, 2014.

Lacan, J. (2008). O Seminário, livro 7: a ética da psicanálise. (A. Quinet, Trans.) orge Zahar. (Original work published 1959-60)

Lacan, J. (2008) O Seminário, livro 16: de um Outro ao outro. (V. Ribeiro, Trans.) Jorge Zahar. (Original work published 1968-69)

Laurent, É. A batalha do autismo: da clínica à política. (C. Berliner, Trans.) Jorge Zahar, 2014.

Lefort, R. \& Lefort, R. (1990) Nascimento do Outro: duas psicanálises, Nadia, 13 meses, Marie-Françoise, 30 meses. $\left(2^{\mathrm{a}}\right.$ ed., A. Jesuino, Trans.) .Fator. (Original work published 1980)
Lefort, R. \& Lefort, R. (2003). La distinction de l'autisme. Le Seuil.

Maleval, J.-C. (2003) De l'objet autistique à la machine: les suppléances du signe. In: F. Hulak (Ed.). Pensée psychotique et création de systèmes: la machine mise à nu. (pp.197-217). Ramonville Saint-Agne: 2003.

Maleval, J.-C. (2007). "Sobretudo verbosos", os autistas. Latusa Revista da Escola Brasileira de Psicanálise, 12, 69-91.

Maleval, J.-C. (2015). Os objetos autísticos complexos são nocivos? [Are complex autistic objects harmful?] Psicologia em Revista, $15(2), 223-254$.

Maleval, J.-C. (2012). Língua verbosa, língua factual e frases espontâneas nos autistas. In: A. Murta, A. Calmon \& M. Rosa (Eds.) Autismo(s) e atualidade: uma leitura lacaniana (pp.4569). Scriptum.

Maleval, J-C. (2012b). Why the hypothesis of an autistic structure? Psychoanalytic Notebooks, 25, 26-48..

Maleval, J-C.(2017). O autista e sua voz. (P. S. Souza Jr., Trans.). Blucher.

Schovanec, J. (2016). Je suis à l'est. Pocket.

Tustin, F. (1992). The Protective Shell in Children and Adults. Karnac Books.

Williams, D. (1999) Nobody, Nowhere - The Remarkable Autobiography of an Autistic Girl. London and Philadelphia: Jessica Kingsley Publishers. (Original work published 1992). 